\title{
Film Mendadak dangdut (2006) Pemahaman geografi budaya dan identitas
}

\author{
BAYU KRISTIANTO
}

\begin{abstract}
ABSTR ACT
Place has certain connotations that are involved in shaping the identity of an individual or a community. Due to the importance of place or location in identity formation, Cultural Studies has its own area of analysis focusing on the understanding of place, which is cultural geography. Peter Jackson (1989: 23, quoted by Giles and Middleton 1999: 104) defines cultural geography as a study on how cultures are constituted by social practises occurring in certain contexts which are influenced by historical and geographical factors. The discussion of artistic works centred on the role of place in identity formation becomes an interesting analysis. This research focuses on Rudi Soejarwo's film Mendadak Dangdut ('Suddenly Dangdut'). The film's setting is a densely populated district in Jakarta. As the plot centres around this setting, an analysis of how place influences the identity formation of the film's main character becomes significant. The research is made using approaches in cultural geography, along with two key concepts in Cultural Studies, which are identity and representation. It is aimed at finding a new consciousness as to how urban context, especially that related to an understanding of place, takes part in the formation of identity of individuals and communities.

KEYWORDS

Geografi budaya (cultural geography), identitas (identity), representasi (representation), esensialisme (essentialism), perkotaan (urban), konteks (context), tempat (place), relasi sosial (social relation), konflik (conflict), kontestasi (contestation), negosiasi (negotiation), pemaknaan (interpretation), tatapan (gaze), globalisasi (globalization), fetish, kamera (camera), fluiditas (fluidity).
\end{abstract}

Dua tahanan wanita yang masih muda bergegas memasuki sebuah toko kecil yang menjual barang kebutuhan sehari-hari. Alih-alih membeli barang yang diperlukan, mereka menuju ke kamar kecil di bagian belakang toko. Di

\footnotetext{
BAYU KRISTIANTO adalah pengajar pada Program Studi Inggris dan pada Kajian Wilayah Amerika serta Lembaga Bahasa Internasional, Fakultas Ilmu Pengetahuan Budaya Universitas Indonesia. Program Magister diselesaikannya pada tahun 2006 di State University of New York, Buffalo, di bidang Kajian Amerika dengan tesis berjudul Man and the World in Heidegger, Emerson, and Native American Philosophy. Ia memiliki minat penelitian di bidang kesusastraan, pemikiran filsafat Amerika dan Inggris, serta Cultural Studies. E-mail: baladewabayu@gmail.com.
} 
dalam kamar kecil ini mereka menemukan jendela terbuka yang hanya cukup untuk dilewati tubuh manusia. Sepertinya ide gila ini muncul begitu saja; Mereka bisa melarikan diri dari kawalan dua polisi sangar yang niscaya akan membawa mereka ke penjara. Maka keluarlah mereka satu persatu melalui jendela WC itu dan mulai berlari sekencang mungkin. Ternyata kedua polisi pria yang berjaga di luar toko menyadari bahwa tahanan mereka kabur. Maka terjadilah kejar-kejaran antara dua orang polisi bertampang garang melawan dua gadis muda yang putus asa karena didakwa sebagai bandar narkoba. Kejar-mengejar empat insan berbeda jenis kelamin ini mengarah ke perkampungan padat penduduk, dan polisi pun celingukan mencari kedua gadis lugu tersebut, namun usaha mereka gagal total. Akhirnya mereka menemukan sebuah pertunjukan dangdut khas kampung padat penduduk maupun kampung pinggiran Jakarta, dengan alat musik dan dekorasi panggung seadanya. Namun, di sini pun mereka harus gigit jari; dua gadis cantik yang menjadi tahanan mereka nampaknya telah kabur dengan sukses. Satu hal yang mereka tidak sadari adalah bahwa salah satu wanita buronan mereka sedang menyanyi di atas panggung dengan wajah bertutupkan cadar, tepat di depan mata mereka sendiri.

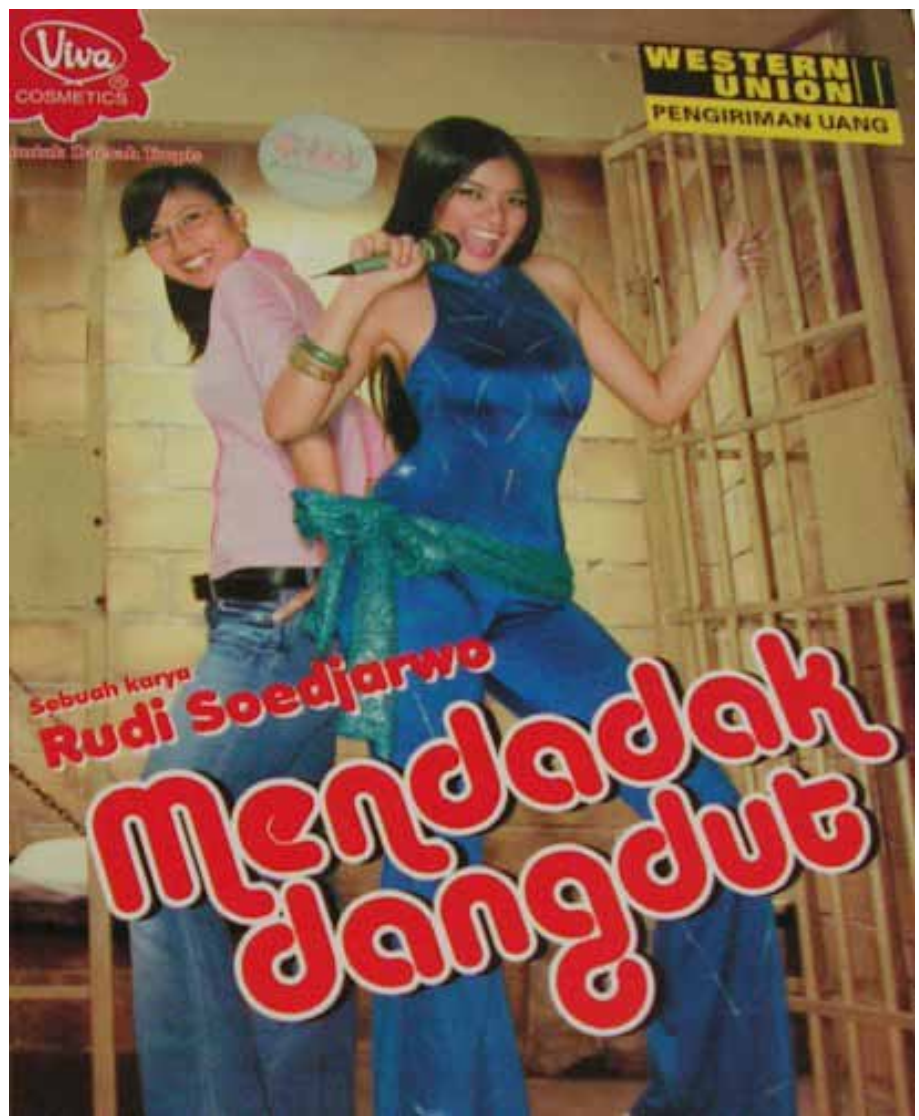

Gambar 1. Film Mendadak Dangdut (2006) karya Rudi Sudjarwo. 
Inilah salah satu adegan menarik di bagian awal film Mendadak dangdut, karya sutradara Rudi Soejarwo (2006) (lihat Gambar 1). Rudi Soejarwo, sutradara film ini, adalah salah satu sutradara muda yang termasuk paling produktif akhir-akhir ini. Semenjak kemunculan film pertamanya, Bintang jatuh, di tahun 2000, ia membuat semakin banyak film yang jarak penciptaannya tidak terlalu jauh satu dengan yang lain. Mendadak dangdut adalah salah satu dari sepuluh film yang masuk seleksi penjurian Festival Film Indonesia (FFI) pada tahun 2006, dan film ini juga masuk dalam seleksi yang dilakukan oleh MTV Movie Awards 2006.

Mendadak dangdut berkisah tentang Patrice, seorang penyanyi lagu-lagu pop rock yang sedang naik daun, dan kakaknya, Yulia, yang berperan sebagai manajer bagi adiknya sendiri. Mereka tertangkap polisi dalam sebuah razia narkoba di jalan raya karena Gerry, pacar Yulia, membawa lima kilogram bubuk heroin dalam mobil dan melarikan diri ketika polisi menghentikan mobil mereka. Patrice dan Yulia melarikan diri ke perkampungan padat penduduk, dan untuk menutupi identitas mereka, Yulia memaksa Patrice untuk menjadi penyanyi dangdut dan tampil di pertunjukan-pertunjukan organ tunggal yang dipimpin oleh Rizal. Patrice berhasil menjadi penyanyi dangdut organ tunggal yang amat disukai penonton karena wajahnya yang menawan - meski sebagai seorang penyanyi dangdut suaranya belum terbentuk - sehingga ia pun kembali kondang. Namun, kini ia adalah penyanyi dangdut, bukan lagi penyanyi pop. Sayangnya, keberadaan mereka tercium oleh aparat, dan akhirnya mereka kembali diciduk oleh polisi. Karena terbukti tidak bersalah, yakni dengan tertangkapnya Gerry di Batam, yang mengaku bahwa heroin dalam mobil Patrice adalah miliknya, mereka berdua pun dibebaskan.

Meski cukup dikenal oleh masyarakat Indonesia, tidak banyak ulasan maupun analisis kritis yang dibuat mengenai film ini. Sebagian besar tulisan yang membahas film ini berwujud tulisan populer maupun ulasan informatif dalam surat kabar dan majalah. Pembahasan yang cukup kritis ditulis oleh Eric Sasono, salah satu kritikus film Indonesia yang tulisannya banyak dimuat di media masa akhir-akhir ini, yang berwujud esai lepas berjudul "Ini bukan badut, ini dangdut" dan dimuat dalam situs Layarperak.com. Eric Sasono menganggap bahwa ketiadaan erotisme dalam film ini adalah persoalan yang serius, karena " $[\mathrm{g}]$ oyang para penyanyi organ tunggal sampai saat ini masih membuat goyang ngebor Inul tampak seperti tarian qasidahan" (2007). Pendapat ini mendukung argumennya sendiri bahwa yang diutamakan dalam dangdut adalah eskapisme, yakni bagaimana orang-orang terpinggirkan mampu menemukan sarana untuk lari dari kenyataan, yang dalam hal ini berarti berlari pada imajinasi seksual.

Namun, dalam pandangan saya, pendapat Eric Sasono ini tidak tepat sasaran karena penonjolan erotisme Patrice justru akan mengukuhkan stereotip buruk mengenai musik dangdut dan segala fenomena yang mengitarinya sehingga film ini tidak akan lagi memiliki makna. Konsentrasi pada erotisme akan menjungkirbalikkan visi film ini untuk menjadikan 
dangdut sebagai arena negosiasi dan penciptaan pemaknaan yang berbeda. Ruang (perkampungan miskin) akan kembali identik dengan hal-hal yang tidak pada tempatnya, seperti misalnya kekerasan dan pelecehan seksual.

Eric Sasono berpendapat bahwa penggambaran ruang juga memiliki masalah tersendiri karena seolah-olah permasalahan Yulia dan Patrice di tempat yang baru ini mudah terselesaikan. Ini juga merupakan sebuah pengamatan yang keliru. Eric Sasono gagal untuk melihat betapa kompleksnya faktor ruang mempengaruhi pembentukan identitas dan representasi Patrice; ia tidak berhasil menemukan betapa justru faktor ruang inilah yang mengubah secara total konsep identitas yang dipegang oleh Patrice. Pembahasan karakter tokoh Patrice tidak bisa dipisahkan dari kompleksitas pengaruh ruang tersebut.

Makalah ini berusaha untuk menganalisis film Mendadak dangdut dengan menggunakan pendekatan geografi budaya (cultural geography) dan pemahaman mengenai identitas dan representasi dalam ruang lingkup Cultural Studies. Karena film Mendadak dangdut mengambil latar perkampungan padat penduduk yang dihuni oleh masyarakat kelas bawah, pembahasan akan dipusatkan pada bagaimana latar atau tempat mempengaruhi identitas dan representasi manusia-manusia yang ada di dalamnya serta memberikan pemaknaan dalam relasi sosial-budaya antarmanusia yang menghuni tempat tersebut.

Film ini menarik untuk dikaji karena berhasil menggambarkan bagaimana pergeseran identitas individu dalam konteks perkotaan di satu pihak sulit terjadi dan di pihak lain pada saat yang sama bisa terjadi dengan mudah. Bagi tokoh utama, Patrice, mencoba menjalani kehidupan baru di perkampungan miskin merupakan sesuatu yang sangat sulit untuk dilakukan, namun dengan berubah profesi dari yang semula penyanyi pop-rock terkenal menjadi penyanyi dangdut kelas kampung, ia dapat menghindar dari kejaran polisi dengan begitu mudahnya. Kemampuan individu perkotaan untuk memiliki identitas yang cair ${ }^{1}$ adalah salah satu modal utama dalam kebutuhan untuk bertahan hidup di kota besar. Di samping itu, kemampuan individu untuk berpindah dengan mudah dari satu konteks ke konteks yang lain dalam ruang lingkup perkotaan menjadi kekuatan positif bagi individu tersebut maupun masyarakat di mana ia berada.

Tujuan akhir pembahasan adalah untuk mengetahui bagaimana ruang lingkup perkotaan membentuk manusia yang hidup di dalamnya, serta bagaimana budaya yang hidup di wilayah perkotaan dibentuk oleh pertentangan nilai dan kontestasi pemaknaan yang berbeda-beda namun ingin turut membentuk konsep dan citra mengenai perkotaan dan budaya perkotaan itu sendiri.

\section{GEOGRAFI BUDAYA, REPRESENTASI, DAN IDENTITAS}

Elaine Baldwin et al. (2004: 179) mengatakan bahwa geografi budaya bergelut

$1 \quad$ Yang dimaksud dengan identitas cair adalah jati diri yang fleksibel sehingga mudah memasuki tempat dan konteks yang berbeda-beda. 
dengan upaya untuk memahami keterkaitan antara manusia dan tempat, dan bahwa geografi budaya bukanlah sekedar upaya untuk menempatkan (locating) budaya pada tempatnya yang pas. Atas dasar pemahaman bahwa segala bentuk budaya bersifat sinkretis (dalam arti selalu merupakan percampuran lebih dari satu macam budaya) atau hybrid, keterhubungan antarbudaya menjadi semakin menonjol. Konsekuensinya adalah bahwa mempelajari geografi dari keterkaitan (interconnection) ini menjadi sesuatu yang signifikan. Perlu diingat bahwa keterhubungan itu bersifat lintas batas serta melampaui segala bentuk pembatasan. Budaya dan geografi saling berkelindan dan menjadi salah satu faktor penentu yang membentuk kehidupan masyarakat.

Identitas dibentuk oleh konotasi-konotasi yang muncul ketika manusia hidup pada suatu tempat atau lokasi tertentu. Dengan demikian, geografi budaya membahas bagaimana ruang dan tempat dibentuk oleh - serta membentuk - kepercayaan beserta nilai-nilai yang dipegang oleh masyarakat yang menghuni suatu tempat tertentu, yang dengan sendirinya membentuk identitas masyarakat tersebut. Peter Jackson (1989: 23; dikutip oleh Giles dan Middleton 1999: 104) berpendapat bahwa: "cultural geography [...] focuses on the way cultures are produced and reproduced through actual social practices that take place in historically contingent and geographically specific context". Maka, analisis yang dilakukan dalam geografi budaya terkonsentrasikan pada bagaimana faktor waktu dan ruang mempengaruhi budaya melalui praktek sosial yang terjadi di dalamnya. Tindakan sosial yang mengambil waktu dan tempat tertentu menjadi sesuatu yang penting.

Geografi budaya percaya bahwa tempat bukanlah sesuatu yang bersifat independen atau terpisah dari manusia. Justru, tempat tercipta sebagai produk dari kondisi-kondisi sosial tertentu yang menciptakan tempat tersebut (Giles dan Middleton 1999: 105). Tempat selalu penuh dengan makna, dan karena keterpenuhan makna ini, geografi budaya menekankan pemahaman bahwa hubungan antara tempat dan makna-makna tersebut jangan sampai diabaikan. Tempat harus senantiasa menjadi sesuatu yang diperhitungkan dalam analisis budaya apa pun (Giles dan Middleton 1999: 125).

Sama halnya dengan pendekatan terhadap budaya dalam Cultural Studies, ${ }^{2}$ geografi budaya juga merupakan sebuah arena kontestasi (a contested domain). Pemaknaan dalam geografi budaya tidak selalu sama dalam kurun waktu dan lokasi yang berbeda. Pemaknaan senantiasa berubah, dan pemaknaan baru selalu ingin menggantikan pemaknaan lama. Hal ini disebabkan hubungan antara hidup manusia dan tempat yang mereka huni tidak pernah seragam antara satu tempat dengan tempat lainnya. Karena bentangan budaya (cultural landscape) merupakan sesuatu yang dibentuk oleh manusia dari bentangan

\footnotetext{
Budaya dalam Cultural Studies dipahami sebagai sebuah wilayah konflik. Budaya merupakan sebuah arena di mana kelompok-kelompok sosial yang berbeda-beda berusaha untuk mendefinisikan diri mereka serta membuat nilai-nilai yang mereka pegang diakui dan diterima oleh masyarakat. Ini adalah wilayah dimana kelompok-kelompok sosial berusaha untuk tidak saja mendefinisikan diri mereka sendiri namun juga kelompok-kelompok lain beserta tempat mereka masing-masing di dunia (Baldwin et al. 2004: 137).
} 
yang bersifat alami (natural landscape), maka setiap bentuk bentangan budaya adalah sesuatu yang bersifat spesifik dan lain daripada yang lain (Baldwin et al. 2004: 134-135).

Contoh bahwa geografi budaya merupakan suatu arena kontestasi adalah adanya dua macam geografi dalam satu kota, yakni geografi yang bersifat resmi (official geography) yang dibentuk oleh pemerintah dan pihak-pihak yang memiliki kuasa dan kepentingan tertentu, dan jenis geografi yang - boleh dikatakan - milik rakyat (folk geography) yang berlawanan dengan geografi versi resmi. Dua macam bentuk geografi yang hadir dalam satu tempat ini selalu berada dalam kondisi persaingan untuk menciptakan pengaruh. Salah satu wujud persaingan tersebut adalah dalam hal penciptaan nama tempat. Para pendukung jenis geografi pertama cenderung untuk memberikan nama yang sarat dengan nilai-nilai dan estetika, sedangkan pengikut jenis geografi kedua lebih memilih untuk menggunakan nama yang bersifat antiotoritas, yakni nama yang berkonotasi negatif dan cenderung untuk menyindir atau mengejek sebagai sebuah bentuk perlawanan terhadap pihak yang berkuasa. Pemilihan nama adalah sebuah perwujudan perang budaya antarkelas yang berbeda (Baldwin et al. 2004: 147).

Berkaitan dengan wilayah perkotaan, ada lima unsur kota yang bisa menjadi bagian analisis geografi budaya. Paths (jalur) mengacu pada jalur-jalur di mana individu biasanya bergerak, misalnya jalan, lorong, rel kereta, kanal, serta tempat-tempat transit. Edges (tepi) mengacu pada daerah batas antara dua wilayah, misalnya pantai, rel kereta yang memotong jalan, dan dinding. Districts (kawasan) mengacu pada bagian-bagian kota yang memiliki batas namun bisa dimasuki, yang menimbulkan kesan mental tertentu ketika kita memasukinya, serta memiliki unsur atau ciri-ciri tertentu yang membentuk identitasnya, misalnya, daerah pemukiman elit, perkampungan kumuh, dan wilayah perkantoran mewah. Nodes (titik pertemuan) mengacu pada titik-titik strategis dalam kota di mana individu mengawali atau mengakhiri perjalanannya. Nodes juga berwujud titik-titik pertemuan, misalnya pertigaan atau perempatan, yakni pertemuan atau persilangan dua jalan, di mana individu memiliki kesan berpindah dari satu struktur ke struktur yang lain. Landmarks (bangunan atau benda penanda ruang) mengacu pada sesuatu yang tidak bisa dimasuki karena senantiasa bersifat eksternal. Landmarks berwujud bangunan-bangunan fisik maupun benda-benda alam, baik jauh maupun dekat. Masjid, supermarket, taman, dan monumen merupakan landmarks, sekaligus gunung dan matahari yang jauh letaknya dari pengamat (Baldwin et al. 2004: 401)

Selain interpretasi budaya, perlulah memahami representasi dan identitas. Mengenai representasi, Kathryn Woodward (1997: 14) menulis sebagai berikut:

Representation includes the signifying practices and symbolic system through which meanings are produced and which position us as subjects. Representations produce meanings through which we can make sense of our experience and who we are. [...] Representation as a cultural process establishes individual and collective identities 
and symbolic systems provide possible answers to the questions: who am I?; what could I be?; who do I want to be?

Representasi membentuk individu serta menciptakan identitas kolektif suatu masyarakat karena di dalam representasi inilah makna diciptakan. Dengan demikian, siapa kita secara individu maupun sebagai kelompok lebih ditentukan oleh faktor eksternal, karena representasi dibentuk oleh proses budaya serta sistem simbolik sedemikian rupa sehingga identitas kita terbentuk dan posisi kita sebagai subjek menjadi jelas. Dengan adanya sistem representasi, penciptaan makna dan pembentukan identitas menjadi semakin jalin-menjalin karena dalam sistem representasilah keterhubungan ini terjadi.

Menurut Chris Barker (2000: 11), identitas adalah sesuatu yang tidak memiliki esensi pada dirinya sendiri. Identitas tidak memiliki muatan-muatan yang bersifat universal. Identitas adalah "discursive constructions, the product of discourses or regulated ways of speaking about the world" (Barker 2000:11). Identitas adalah sesuatu yang diproduksi dalam diskursus, dan diskursus itu sendiri dibentuk oleh sejumlah peraturan dan konvensi yang membentuknya, dan menurut Michel Foucault, diskursus adalah apa yang mendefinisikan serta menciptakan obyek-obyek pengetahuan (Barker 2000: 20). Identitas adalah sesuatu yang bersifat buatan; sesuatu yang dibentuk oleh representasi dan bukan sesuatu yang dibentuk secara alami. Faktor utama pembentuk identitas adalah bahasa. Menurut Jaques Lacan, manusia adalah "subjek dari proses struktural bahasa" karena "[d]i dalam dan melalui bahasalah manusia menjadi subjek [...]" (Storey 2007:77-78). Oleh sebab subjek dan subjektivitas hanya ada dan dibentuk oleh bahasa, maka identitas, yang berfondasi pada subjektivitas, tidak pernah berdiri sendiri. Identitas tergantung dan terbentuk oleh faktor eksternal, seperti misalnya bahasa sebagai tatanan simbolik eksternal di mana manusia masuk ke dalamnya untuk menemukan subjektivitasnya dan menjadi anggota masyarakat.

Identitas adalah murni produk dari konstruksi sosial. Identitas selayaknya tidak dipahami sebagai sesuatu yang bersifat tetap dan tidak berubah, namun sebagai "an emotionally charged description of ourselves" (Barker 2000: 166). Itu disebabkan identitas bersifat emosional, tidak pernah tetap, dan relasional, yakni tergantung dengan siapa individu menjalin relasi pada konteks tertentu. Dengan demikian, identitas bersifat sementara (contingent) karena identitas bisa berubah bergantung pada konteks di mana individu berada. Dalam pembentukan identitas tersebut ada dua proses yang terjadi, yaitu penolakan (exclusion) dan penerimaan (inclusion) karena membentuk identitas berarti menolak hal-hal yang bertentangan dan merangkul hal-hal yang sesuai dengan identitas tersebut. Identitas juga tidak pernah netral; di dalamnya selalu terdapat nilai-nilai yang saling berbenturan. Di dalam identitas terjadi jurang atau gap, yaitu antara representasi dan kenyataan (Giles dan Middleton 1999: 34). 
IDENTITAS, REPRESENTASI, DAN PEMAKNAAN DALAM MENDADAK DANGDUT

Film Mendadak dangdut diawali dengan adegan Patrice menyanyikan lagu pop, yang dikenal luas oleh publik. Dia percaya bahwa identitas dirinya sebagai penyanyi pop dan segala fasilitas dan kemudahan yang bisa ia nikmati merupakan dua hal yang tidak terpisahkan. Ia telah terbiasa dengan kemewahan, sebagai contoh, sedan yang ia naiki untuk pulang ke rumah adalah sedan mewah hasil keringatnya, yang juga dinikmati oleh Yulia, kakaknya sendiri, sekaligus manajer pribadinya. Ia tidak merelakan sedan pribadinya rusak, sehingga ia menolak ketika Yulia memilih untuk mengambil jalan yang berbeda dari jalan yang selama ini ia lewati.

$\begin{array}{lll}\text { Patrice } & : & \text { Kak, Kak, lu ngapain lewat sini? Lewat sana kan lebih cepat? } \\ \text { Yulis } & : \text { Lewat sini lebih cepat. Percaya aja deh. } \\ \text { Patrice } & : \text { Ya tapi kan lubangnya banyak. Nanti kalau kena mobil gue, } \\ & \text { rusak, ke bengkel, bayar lagi. } \\ \text { Yulia } & : \text { Lu potong aja dari komisi gue. } \\ \text { Patrice } & : \text { Bener ya? (dengan nada mengancam) }\end{array}$

Bagian ini menyiratkan satu hal penting, yakni bahwa ada bagian-bagian kota, yang di sini berwujud paths atau jalan-jalan dalam kota, yang perlu dihindari karena menimbulkan ketidaknyamanan. Adegan ini adalah semacam foreshadowing ${ }^{3}$ tentang apa yang akan senantiasa dilakukan Patrice selanjutnya: ia akan melakukan penghindaran demi penghindaran. Ini adalah wujud tindakan penolakan (exclusion) akan hal-hal yang tidak sesuai dengan identitasnya. Ia berusaha untuk tetap menjaga keutuhan identitasnya dengan menolak segala sesuatu yang berlawanan dengan identitas dirinya. Di sini kita melihat hubungan yang dekat antara lokalitas atau tempat (jalan berlubang, yang harus dihindari) dengan identitas (Patrice, sebagai penyanyi termasyhur, yang tergabung dalam kelas sosial tertentu). Demi menjaga suatu bentuk identitas yang mutlak, penjagaan akan identitas harus sekaligus berwujud penghindaran akan segala sesuatu yang berlawanan dengan identitas tersebut.

Hal yang menarik terjadi dalam adegan berikutnya. Patrice dan Yulia berusaha melarikan diri dari kejaran polisi. Mereka berdua berlari memasuki perkampungan padat penduduk sampai akhirnya tiba dan berhenti di sebuah pertigaan. Adegan melarikan diri ini ditampilkan oleh Rudi Soejarwo, sang sutradara, dengan traveling shot, yaitu pengambilan gambar dengan kamera yang mengikuti objek bergerak. Namun, alih-alih menggunakan dolly dan track (alat untuk mengambil gambar yang berjalan di atas rel kecil), sutradara mengambil gambar dengan kamera yang turut berlari di belakang dan di samping Patrice dan Yulia. Efeknya adalah gambar yang bergerak cepat dan sekaligus kacau dan tidak terfokus. Mata kita dipaksa untuk mengikuti setiap bentuk gerakan cepat tersebut, dan kita pun seolah merasa pusing.

Foreshadowing adalah bagian-bagian cerita yang memberikan petunjuk mengenai apa yang akan terjadi pada bagian berikutnya. 
Apakah relevansi dari adegan ini? Ini diinterpretasikan sebagai sebuah momen titik balik. Pertigaan bisa dipahami secara simbolik: Patrice tiba di suatu titik percabangan ketika ia harus "berbelok" dari identitasnya semula yang berusaha ia jaga dengan kukuh. Patrice dipaksa untuk mulai meninggalkan identitasnya yang lama dan kaku. Kekacauan pengambilan gambar yang kita saksikan juga bersifat simbolik: bagi Patrice melepas kekakuan identitas bukanlah sebuah proses yang mudah. Ini adalah sebuah awal penjungkirbalikan pemahaman akan identitas, seperti halnya gerak mata kita yang seolah-olah dijungkirbalikkan oleh metode pengambilan gambar. Yang menarik adalah bahwa perubahan sikap dan pemahaman akan identitas terjadi sejalan dengan masuknya Patrice ke perkampungan padat penduduk di salah satu sudut Jakarta. Kita melihat kembali berkelindannya pembentukan identitas dengan peran lokalitas.

Bila kita amati lebih seksama, mereka berdua berlari memasuki perkampungan yang semakin ke dalam semakin buruk dan tidak teratur kondisinya. Hal ini seolah-olah memberi petunjuk pada kita bahwa kini Patrice dan Yulia memasuki suatu wilayah baru yang akan menjurus ke hal-hal yang semakin negatif berkenaan dengan identitas mereka. Kita juga dihadapkan pada suatu bentuk pemahaman yang lain: bahwa musik pop (yang mengacu pada Patrice) berhubungan dengan tempat yang bersih, rapi, nyaman, dan teratur, sementara musik dangdut selalu dikonotasikan dengan yang kumuh, yang tidak teratur, tidak berkualitas, dan tidak nyaman. Kata-kata yang diucapkan oleh Patrice semakin memperjelas hal ini.

$\begin{array}{lll}\text { Patrice } & : & \text { (terengah-engah karena berlari) Lu sih Kak! Nyuruh belok segala. } \\ & & \text { Nyasar, kan?! } \\ \text { Yulia } & : & \text { (Juga terengah-engah karena berlari) Patrice, kita kan buronan? } \\ & & \text { Lu maunya kabur ke mana, sih, Pat? Ke mal? } \\ \text { Patrice } & : & \text { Kalau ke mal kan bisa beli makanan?! Laper nih!! } \\ \text { Yulia } & : & \text { Mau bayar pake apa, Pat? } \\ \text { Patrice } & : \text { S } & \text { Suruh aja orang foto bareng ama gue! Beres, kan?! } \\ \text { Yulia } & : & \text { Ide bagus, tuh, Pat. Kenapa nggak sekalian aja lu telpon polisi? } \\ & \text { Prus kasih tahu kita ada di mana? Lu mau mati, Pat? }\end{array}$

Menarik untuk mengamati bagaimana tempat berperan besar dalam membentuk identitas Patrice. Mal bukanlah sebuah tempat tanpa makna, justru mal adalah sebuah sistem representasi. Siapakah Patrice didefinisikan oleh dan di dalam mal. Identitas Patrice menjadi established di tempat ini. Namun, kini kemewahan harus dihadapkan dengan antitesisnya: kemiskinan. Esensialisme identitas muncul: identitas Patrice harus tetap satu, yang selalu harus didukung oleh kenyamanan dan kemewahan. Seandainya Patrice tidak pernah memasuki situs kemiskinan semacam ini, tentu ia akan tetap percaya bahwa identitas dirinya adalah sesuatu yang solid. Pemahaman ini dipertegas pada adegan pendek berikutnya, yakni ketika ada tiga orang pemuda kampung yang akan berbelok di tikungan di mana mereka berhenti. 
Salah satu dari mereka nyeletuk pada Patrice:

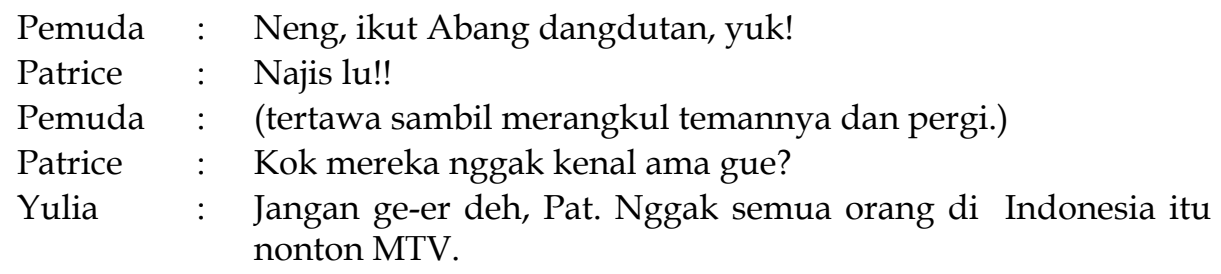

Dari dialog di atas kita bisa mengetahui sikap Patrice terhadap musik dangdut. Musik dangdut adalah sebentuk musik yang, bisa dikatakan, "menjijikkan" baginya. Kata "najis" mungkin tidak harus bermakna "haram" di sini, dan bisa saja mengacu pada musik dangdut itu sendiri maupun pemuda tersebut, namun pemakaian kata "najis" jelas menunjukkan bahwa musik dangdut adalah sesuatu yang harus dihindari oleh Patrice. Sementara ada kedekatan tersendiri antara para pemuda kampung miskin tersebut dengan musik dangdut, maka Patrice menjaga sikap antipati terhadap jenis musik ini. Dua macam identitas ini berbenturan untuk pertama kalinya tepat pada titik ini, yang berwujud sebuah node atau titik pertemuan. Maka tempat - khususnya node pada bagian ini - mampu menciptakan konflik, dan tempat pun menjadi arena kontestasi. Dangdut dan pop, dan manusia-manusia yang diwakilinya, dengan identitasnya masing-masing, bertabrakan tepat di sebuah pertigaan di perkampungan miskin.

Namun, ternyata pendefinisian musik dangdut pun menjadi sebuah arena kontestasi. Rizal, seorang pemuda yang hidup dari kampung ke kampung dengan mengusung pertunjukan organ tunggal, berdebat hebat dengan Veti Manis Madu, penyanyi dangdut yang biasa bernyanyi dengan organ tunggalnya, tentang apa sesungguhnya musik dangdut itu. Bagi Veti, dangdut tidak memiliki makna apa-apa. Yang terpenting dalam menyanyi dangdut adalah bagaimana goyang pantatnya mampu memukau penonton dan mendatangkan uang. Bagi Rizal, yang harus diutamakan dalam pertunjukan dangdut adalah musik dangdut itu sendiri, bukan gerakan erotis yang kerap membungkusnya.

\footnotetext{
Veti : Mereka semua ke sini cuma mau nonton aku, Veti Manis Madu.

Rizal : Eh, lu dengerin gue dulu ya. Lu dengerin gue dulu. Semua orang yang datang itu ingin menonton musiknya. Nggak ada yang mau lihat pantat lu.

Veti : Oalah, Mas, musik opo? Iki lho, pantatku iki lho, Mas.

Rizal : Dasar lonte lu!!

Veti : (Menampar Rizal dengan sangat keras.) Wis, aku bener-bener nggak mau nyanyi buat Mas Rizal lagi. Cari penyanyi lain, Mas. Aku cuma mau goyang pantat!

Rizal : Asal lu tahu ya, yang penting musik! Bukan pantat!
} 
Sementara harus berhadapan dan berbenturan dengan musik pop, dangdut pun harus berurusan dengan konflik dalam dirinya sendiri. Ketika individu yang terlibat dalam musik dangdut berusaha mendefinisikan apakah musik dangdut tersebut, masing-masing definisi merefleksikan hasrat dan selera tiap orang mengenai musik dangdut sehingga terjadi konflik dalam upaya pendefinisian ini. Pendefinisan musik dangdut menjadi pergulatan dan kontestasi identitas. Dalam pemahaman akan identitas, mengatakan siapakah kita berarti memasuki ranah konflik, karena siapakah kita berhubungan dengan penegasan akan kepercayaan, kebutuhan, dan hasrat individu atau kelompok yang berbeda-beda. Hal ini sejalan dengan pendapat Jeffrey Weeks (1990: 88-89, dikutip oleh Giles and Middleton 1999: 51), yang mengatakan bahwa "By saying who we are, we are also striving to express what we are, what we believe and what we desire. [...] these beliefs, needs and desires are often patently in conflict, not only between communities, but between individuals themselves".

Hal yang sama terjadi dalam pemaknaan dangdut. Individu-individu yang menjadi para pelaku musik dangdut berada dalam konflik mengenai identitas musik dangdut itu sendiri. Identitas musik dangdut pun merupakan sesuatu yang terpecah, serta dimaknai secara berbeda oleh pelbagai individu yang berbeda-beda. Bila kita berpegang pada pendapat Veti, maka dangdut akan menjadi suatu ranah yang terpecah oleh gender (a gendered space). Artinya, dangdut hanya akan menjadi milik perempuan yang memiliki pantat untuk digoyang demi memberi kenikmatan pada lelaki. Dangdut bernasib sama seperti ruang: terpecah menurut gender. Namun, dalam dangdut pembagian itu terjadi secara tidak adil. Bila mengikuti pandangan Veti, dangdut bukanlah ranah milik laki-laki; kaum laki-laki harus dikeluarkan dari wilayah ini karena diangap tidak relevan (dikaitkan dengan kenyataan bahwa tidak banyak penyanyi dangdut pria yang dinikmati penonton karena goyangan pantat mereka), dan justru kaum perempuanlah yang dianggap paling tepat untuk mengisi wilayah ini.

Namun, dengan mengisi ranah ini, perempuan harus menjadikan dirinya objek eksploitasi tatapan mata (gaze) yang bersifat seksual dari kaum lelaki, atau sentuhan fisik pada situasi yang ekstrim. Menurut saya, pendapat Rizal justru lebih baik dan netral. Dangdut adalah milik siapa saja dan tidak terbagi secara tidak adil menurut gender. Bukan keperempuanan atau kelelakian yang bisa mengisi dangdut, namun musik dangdut itu sendiri yang selayaknya mengisi dangdut dan tidak memandang serta membedakan gender dan jenis kelamin.

Identitas Patrice menjadi tidak berarti di perkampungan di mana Patrice dan Yulia melarikan diri dari kejaran polisi. Hanya tinggal dirinya sendiri dan Yulia yang masih percaya akan identitas Patrice sebagai penyanyi pop. Bahkan Rizal pun sama sekali tidak mengenal Patrice sebagai penyanyi pop terkenal.

Yulia : Kita kan buronan. Kita nggak punya uang, nggak punya tempat tinggal. Masuk akal dong kalau kita sembunyi sama Bang Rizal. 
Patrice : Konsep sembunyi maksud lu adalah dengan manggung di depan ratusan orang?

Yulia : Di depan ratusan orang yang nggak kenal siapa Patrice. Mereka kenalnya siapa? Inul, Uut Permatasari, Dewi Persik ...

Patrice : Kok gitu? Cakepan juga gue daripada mereka.

Yulia : Patrice, lu inget nggak? Waktu lu naik ke atas panggung, polisi yang ngejar kita nggak ngenalin lu, kan? Karena di otak mereka yang mereka cari itu bukan penyanyi dangdut.

Adegan ini membuktikan kebenaran kata-kata Baldwin et al. (2004: 148) bahwa representasi selalu terbentuk dari posisi tertentu dan bergantung pada hubungan-hubungan sosial yang ada. Isi dan bentuk dari representasi ditentukan oleh konteks di mana suatu entitas berada. Representasi publik terhadap Patrice sebagai selebritis ternyata hanya berlaku dalam ruang dan tempat atau konteks tertentu. Ketika memasuki area baru yang berpenghuni manusia dari posisi sosial yang berbeda dari tempat di mana Patrice sebelumnya berasal, representasi itu tidak lagi bermakna. Manusia-manusia di lingkungan yang baru ini akan membangun representasi tersendiri terhadap Patrice. Kini, Patrice harus menyesuaikan dirinya di tempatnya yang baru. Dengan kata lain, identitas diri dan representasi tentang dirinya akan berubah total. (Mungkin mereka seakan-akan ingin "bersembunyi" dari perubahan ini, namun "persembunyian" ini meletakkan mereka pada posisi tertentu, yang menghasilkan representasi dan identitas baru. Itulah sebabnya mereka gagal dalam aksi sembunyi mereka.)

Tersirat dari kata-kata Yulia, di otak para penduduk perkampungan itu, Patrice bukanlah penyanyi pop terkenal. Patrice tak lebih dari sekedar penyanyi dangdut kacangan, bahkan di mata Rizal sekalipun. Patrice yang pada awalnya memilih untuk makan di mal, sekarang harus rela makan nasi bungkus dengan lauk seadanya di rumah kontrakan yang jauh dari mewah di sebuah perkampungan miskin. Di tempat ini, orang bisa makan dengan bersendawa sesuka hati mereka, seperti yang dilakukan oleh Rizal, sesuatu yang enggan untuk dilakukan di mal atau restoran-restoran mewah di bagian kota yang lain. Ini menunjukkan bahwa kota itu sendiri adalah juga suatu ranah yang terbagi-bagi, dan kota itu bukanlah satu. Sebagai arena pergumulan berbagai macam kepentingan, "satu kota sekaligus adalah banyak kota" (a city is many cities) (Westwood dan William 1997: 6, dikutip oleh Barker 2000: 317). Di tempat ini Patrice baru menyadari bahwa kota tidak hanya memiliki satu definisi atau pemaknaan. Terhadap kota terjadi perebutan pemaknaan oleh kelompok sosial yang beragam, dan kini pun ia harus berhadapan dengan suatu pemaknaan akan kota yang berbeda dari yang selama ini ia ketahui.

Sendawa yang bebas lepas tanpa memperdulikan orang lain adalah sebuah antitesis dari kesantunan kelas menengah. Patrice pun harus terkejut dengan ekspresi kampungan seperti ini. Ia lupa, bahwa tindakan semacam ini tidak bisa dimaknai secara terpisah dari konteks di mana mereka berada, yang menentukan baik bentuk maupun isi dari tindakan tersebut, yang 
merepresentasikan kelas dari penghuni perkampungan tersebut dalam masyarakat.

Lokasi pertunjukan musik dangdut di mana Patrice tampil perlu diamati secara lebih dekat. Lokasi ini adalah tepat di sepetak tanah lapang yang tidak terlalu besar di tengah rumah-rumah penduduk. Tenda kotak warna putih didirikan di depan panggung yang sederhana. Sebagai latar panggung adalah spanduk lebar bertuliskan "Organ Tunggal/Senandung Citayam/Pimpinan Risal Saleh Alkat HP 08128737779". Sesuai dengan namanya, hanya ada satu alat musik di tempat itu, yakni sebuah keyboard, yang bisa menghasilkan berbagai irama musik. Satu mikrofon ada di depan Rizal sang pemimpin dan sekaligus pemain musik. Mikrofon kedua dipegang oleh Patrice sebagai penyanyi.

Selain ketiga benda ini (dan dua pengeras suara ukuran sedang), tidak ada alat-alat elektronik yang lain. Antara penyanyi dan penonton tidak ada pembatas apapun, semacam pagar besi atau bodyguard dalam jumlah banyak. Hanya nampak seorang satpam kampung yang berusaha mengendalikan massa. Massa penonton terkadang mulai liar seiring dengan nikmatnya mereka bergoyang dan bersenggol-senggolan. Patrice melihat bahwa di antara penonton terdapat banyak preman. Ia pun sempat ketakutan dengan keberingasan mereka. Terutama saat salah seorang dari mereka naik ke panggung untuk melemparkan uang.

Pemandangan lokasi di mana mereka berada menunjukkan kesederhanaan perkampungan dan penduduk perkampungan tersebut. Namun, tempat ini memiliki makna tersendiri karena justru di tengah-tengah perkampungan padat dan miskin, penduduk kampung tersebut mampu sejenak melepaskan diri dari beban kehidupan yang menghimpit dengan menyaksikan tontonan dangdut sederhana. Maka tanah lapang sempit di mana pertunjukan dangdut diadakan bermakna positif: ia adalah sebuah ranah kelegaan dan kebebasan. Penduduk kampung ini memaknai sepetak tanah sempit - yang bisa kita anggap sebagai suatu landmark dan sekaligus node - dengan cara yang berbeda dari penduduk di bagian kota yang lain, meski dengan cara yang bersahaja. Ini adalah tempat di mana makna-makna baru diciptakan. Tempat ini adalah medium interaksi sosial yang sangat berguna, dan sekaligus menjadi pembentuk dan sesuatu yang dibentuk oleh interaksi sosial budaya masyarakat kampung tersebut.

Kebebasan masyarakat perkampungan ini menarik karena berkontestasi dengan kesempitan ruang di mana mereka berada. Sementara penduduk kelas menengah ke atas memiliki ruang yang jauh lebih lega dan nyaman, faktanya adalah bahwa mereka terperangkap dalam berbagai konsumsi yang bersifat materialistik. Dengan kata lain, kelegaan ruang yang mereka miliki berkontestasi dengan "kesempitan" pemaknaan hidup karena pemenuhan kebutuhan konsumtif justru cenderung membatasi kehidupan mereka. 
Penggambaran tempat pertunjukan dangdut dalam film Mendadak dangdut mengimplikasikan bahwa dangdut adalah milik rakyat jelata, ${ }^{4}$ dan penyanyi dangdut perempuan didatangkan untuk memuaskan kehausan pria akan hiburan sekaligus kemolekan dan kelembutan wajah dan tubuh perempuan. Sesungguhnya, pertunjukan musik dangdut adalah sebuah wilayah negosiasi. Pendapat umum cenderung mengatakan bahwa musik dangdut adalah musik yang digunakan untuk mempermainkan dan mengumbar nafsu lelaki. Pandangan ini sesuai dengan pendapat Veti Manis Madu, yakni bahwa penonton dangdut hanya perlu melihat goyangan pantat. Namun, apa yang ditampilkan oleh Rudi Soejarwo sama sekali berbeda. Saat Patrice mulai menyanyi, hampir tidak seorang penonton pun yang menatap ke arah tubuh seksi Patrice. Setiap orang sibuk untuk bergoyang mengikuti irama dangdut yang dinyanyikan. Meski hampir seluruh penonton adalah kaum lelaki, yang mereka nikmati adalah musik dangdut itu sendiri, bukan sisi kewanitaan Patrice. Di sini Patrice bukanlah korban dari tatapan lelaki. Justru ia mampu menghindar dari tatapan tersebut dengan menciptakan sesuatu yang mampu mengalahkan kenikmatan seksual dari tatapan tersebut. Ia mungkin melayani kepentingan mereka akan pemenuhan hiburan sebagai alat untuk sejenak melupakan kesulitan hidup. Namun, di sini ia adalah pengendali yang mampu menggerakkan suasana sesuai dengan yang ia inginkan. Dengan goyangan dan nyanyiannya, ia mampu menciptakan kerusuhan dan sekaligus perdamaian di antara penonton yang berkelahi.

Setting di pertunjukan berikutnya justru lebih sederhana. Tidak ada tenda apa pun yang memayungi penonton. Hanya ada spanduk yang sama yang dibentangkan di belakang panggung. Panggung pun cenderung untuk menyatu dengan penonton. Panggung ini pendek, hanya berbeda tinggi sedikit dari permukaan tanah di mana para penonton berjoget. Hal yang sama terjadi dalam pertunjukan ini: tidak ada tatapan mata lelaki yang berusaha menelan bulat-bulat wajah dan tubuh penyanyi. Sang penyanyi tidak pernah sekalipun tunduk dan menjadi mangsa tatapan lelaki. Tatapan mata di sini menjadi sesuatu yang tumpul. Patrice justru mampu menatap penonton dengan bebas dari atas panggung dan mampu menguasai mereka.

Berikutnya, sebagai bagian dari kebudayaan populer, musik dangdut sering dianggap dan diperlakukan sebagai suatu bentuk fetish kultural. Ada hal yang menarik dalam hubungan antara dangdut sebagai fetish kultural dengan pemaknaan akan tempat dalam film ini, yang mengambil setting

$4 \quad$ Pendapat umum mengatakan bahwa musik dangdut adalah bagian dari kebudayaan populer di Indonesia yang kerap diasosiasikan dengan kaum kelas bawah. Karena menjadi bagian dari kebudayaan populer, dangdut juga dianggap sebagai budaya inferior. Mereka yang cenderung berpegang pada esensialisme budaya berpendirian bahwa di dalam dangdut tidak ada nilai-nilai budaya yang luhur yang bisa dijadikan pusat dari rasa dan jiwa seni maupun nilai-nilai moral. Musik dangdut tidak selayaknya menjadi patokan dan panutan bagi masyarakat. Sebagian bahkan menganggap bahwa musik dangdut adalah sejenis musik "sampah" yang tidak layak dimainkan dan didengarkan oleh mereka yang sadar akan nilainilai kesenian yang adiluhung. Musik dangdut dianggap tidak layak untuk dianggap serius dan dilestarikan, dan banyak anggota masyarakat yang cenderung segan untuk menganggap bahwa dangdut adalah bagian dari budaya bangsa yang layak dilestarikan. Sedikit uraian mengenai kebudayaan populer bisa dibaca dalam tulisan Manneke Budiman (2003: 138). 
perkampungan padat penduduk yang dihuni oleh masyarakat kelas bawah. Kita perlu memahami bagaimana penduduk di perkampungan bersikap terhadap musik dangdut dan Patrice sebagai penyanyi dangdut baru di kampung mereka. Dengan melakukan analisis ini, akan semakin jelas bahwa konteks atau tempat tertentu mempengaruhi pemahaman individu atau kelompok mengenai suatu fenomena budaya, dan bahwa tidak mungkin terdapat pemaknaan tunggal mengenai suatu fenomena budaya tertentu.

Manneke Budiman (2003: 137) menulis bahwa fetish merupakan sesuatu yang mampu menyuguhkan kenikmatan lebih, yakni suatu kenikmatan yang tidak mampu didapatkan dari perilaku seksual yang tidak menyimpang. Oleh karena besarnya kenikmatan ini, maka fetish selalu cenderung untuk dieluelukan. Akan tetapi, di samping memberikan kenikmatan, pada saat yang sama fetish juga bersifat membatasi dan mengendalikan. Ia tidak memberikan apa yang diinginkan oleh audience atau "korban"-nya dengan bebas begitu saja. Justru oleh fetish sesuatu yang seolah-olah ingin ia berikan akan ditarik kembali. Maka, sesungguhnya kenikmatan yang diberikan oleh fetish adalah kenikmatan yang tidak pernah paripurna. Fetish cenderung bersifat penolakan, dan lebih bersifat "neurotik".

Fetish kultural pun sering memanfaatkan tubuh perempuan, yang wujudnya banyak kita lihat dalam film-film, iklan-iklan, novel-novel, situssitus internet, ataupun media-media budaya yang lain. Tubuh perempuan dimanipulasi sedemikian rupa sehingga produk visual yang menggunakan tubuh tersebut mampu "menimbulkan efek tertentu pada para pemandang atau penikmatnya". Dalam produk komersial tersebut "pandangan [...] voyeristik [pria] menggantikan peran sentuhan dan sasaran seksual yang normal dalam memberikan kenikmatan". Kelembutan tubuh perempuan yang dibiarkan terbuka sebagian sengaja ditonjolkan agar mampu memunculkan efek yang besar pada laki-laki yang melihatnya (Budiman 2003: 141).

Namun, ada sesuatu yang menarik di sini. Film Mendadak dangdut justru tidak memperlakukan dangdut sebagai fetish kultural. Film ini tidak memperlihatkan pertunjukan musik dangdut di mana laki-laki mengarahkan dan "menancapkan" tatapan matanya pada tubuh penyanyi dangdut perempuan. Tidak ada adegan di mana kita bisa melihat bahwa laki-laki memperoleh kenikmatan dari tindakan memandang. Kelembutan dan kemolekan tubuh perempuan yang ditawarkan oleh Patrice justru diabaikan oleh para penonton pertunjukan yang hampir seluruhnya pria. Dengan demikian, meski penyanyi dangdut kerap menjadi bagian dari suatu fetish kultural bagi laki-laki, film ini justru menunjukkan bahwa tubuh perempuan sang penyanyi dangdut - atau bagian-bagian dari tubuhnya - mampu untuk tidak berfungsi sebagai fetish. Patrice memang menawarkan tubuhnya untuk menimbulkan kenikmatan fetish bagi penonton laki-laki, namun uniknya, para penonton justru tidak menyambut dan memperoleh kenikmatan dari penawaran ini. Mereka memperoleh kenikmatan dari musik dangdut itu sendiri, bukan dari pandangan atau tatapan atas tubuh Patrice. Penggambaran ini sesuai dengan pendapat Rizal, pemimpin kelompok dangdut Senandung 
Citayam, bahwa dalam pertunjukan dangdut, yang penting adalah musik dangdut itu sendiri, bukan goyangan pantat penyanyi dangdut perempuan. Veti Manis Madu, yang berbeda pendapat dengan Rizal, justru mengafirmasi pemahaman mengenai dangdut sebagai fetish kultural. Nampak bahwa Rudi Soejarwo cenderung untuk menolak pendapat umum mengenai dangdut sebagai fetish kultural, yang cenderung esensialis dan tidak konstruktif.

Dalam film ini, Rudi Soejarwo tidak memperlihatkan adanya tatapan laki-laki (male gaze) yang intens terhadap sosok Patrice. Bahkan tatapan lakilaki bisa dikatakan absen dalam film ini. Tidak ada laki-laki dewasa pada setiap pertunjukan Patrice yang diperlihatkan memperoleh kenikmatan dari tindakan memandang tubuh Patrice. Penonton laki-laki film ini juga tidak akan menemukan tokoh pria yang layak dengan siapa ia bisa mengidentifikasikan dirinya. Uniknya, Rudi Soejarwo tidak hanya membuat tatapan laki-laki tidak relevan, namun ia justru meremehkan dan menertawakan signifikansi dari tatapan tersebut. ${ }^{5}$

Tatapan pria pada tubuh Patrice tidak muncul dari mata laki-laki dewasa, namun dari mata sesosok anak laki-laki kecil yang dimunculkan dalam film untuk menimbulkan kejenakaan. Anak laki-laki itu adalah Mamat, yang ketika berjumpa untuk pertama kalinya dengan Patrice langsung mengatakan bahwa buah dada Patrice nikmat untuk dilihat, atau dalam ungkapannya sendiri, buah dada Patrice "yahud". Mamat selalu menggoda Patrice karena buah dadanya itu, dan Patrice selalu mengusir Mamat dengan kesal karena merasa dilecehkan secara seksual oleh anak kecil. Ketika berada bersama Patrice, Mamat selalu berusaha untuk memandang ke arah buah dada Patrice, baik secara terang-terangan maupun secara sembunyi-sembunyi.

Meski sekilas ini merupakan suatu wujud pelecehan seksual, saya memaknainya secara berbeda. Dengan menggunakan figur anak kecil untuk menggoda Patrice secara seksual, dan dengan menunjukkan bahwa para pria dewasa dalam film tersebut diperlihatkan tidak memperoleh kenikmatan dari tindakan memandang, Rudi Soejarwo ingin menunjukkan bahwa di dalam musik dangdut itu sendiri, dan di sebuah pemukiman miskin di kota besar, kekuasaan dari tatapan laki-laki bukanlah sesuatu yang senantiasa relevan, seperti yang dipercayai oleh sebagian masyarakat, termasuk Patrice sendiri sebelum ia semakin mengenal lebih dalam kehidupan di kampung tersebut. Musik dangdut dan perkampungan miskin tidak selalu diidentikkan dengan pelecehan terhadap perempuan karena, bahkan di wilayah yang dianggap inferior ini, justru tatapan laki-laki bisa menjadi tidak bermakna. Tatapan

5 Intan Paramadhita (2007) menemukan dalam film Pasir berbisik bahwa sosok perempuan tidak selamanya menjadi korban dari tatapan laki-laki. Melalui tokoh Berlian, ia menunjukkan bahwa perempuan mampu mematahkan tatapan laki-laki, menjadi yang berkuasa terhadap tatapan itu, dan mampu mencegah baik tokoh laki-laki maupun penonton laki-laki untuk memperoleh kenikmatan dari tindakan memandang tokoh perempuan dalam film. Tepat ketika tokoh dan penonton laki-laki mulai bergembira karena seolah-olah akan mendapatkan kenikmatan dari objek fetish mereka, Berlian menghancurkan kenikmatan itu dengan membalikkannya dengan tatapan perempuan (female gaze), dan dengan tidak diperlihatkannya oleh sang sutradara tubuh telanjang Daya, gadis remaja anak dari Berlian, ketika dipaksa untuk bermasturbasi. 
laki-laki malah menjadi suatu lelucon yang justru layak untuk ditertawakan dan diabaikan begitu saja, seperti Patrice yang semula terganggu dengan celetukan-celetukan seksual Mamat, namun kian lama kian tidak peduli dengan tingkah laku Mamat. Bahkan kemarahannya berubah menjadi belas kasihan ketika ia tahu bahwa ibu Mamat disiksa oleh majikannya di Arab Saudi, kehilangan seluruh uangnya, dan tidak bisa menyunatkan Mamat.

Mamat, satu-satunya tokoh dalam film ini yang "menerapkan" dan memanfaatkan male gaze di sebuah perkampungan miskin, justru berubah menjadi figur yang lemah dan tak berdaya ketika ia menangis di samping ibunya yang mengalami luka fisik karena disiksa majikannya. Ironisnya, justru Patrice yang menolong Mamat dan memperoleh rasa hormat dari Mamat dengan kerelaannya untuk mengumpulkan uang dengan menyanyi dangdut di depan masyarakat sekeliling rumah kontrakan mereka. Berkat Patrice, kini Mamat bisa disunat. Tujuan dari sunat itu sendiri, menurut ibu Mamat, adalah supaya Mamat mampu mengendalikan nafsu seksualnya. Dengan demikian, diharapkan bahwa setelah Mamat disunat, male gaze itu akan berkurang atau tidak ada lagi pada dirinya. Sunat yang dialami Mamat menjadi semacam simbol dari terputusnya male gaze di perkampungan ini. Maka, kita melihat bahwa Patrice sendirilah yang akhirnya mampu memadamkan male gaze tersebut. Tatapan laki-laki yang kini kehilangan kekuatannya akhirnya malah tunduk dalam pengaruh dan belas kasihan perempuan.

Ketika tatapan laki-laki di tempat-tempat elit justru seringkali menelan bulat-bulat tubuh perempuan dan bahkan digunakan sebagai sarana untuk mencari uang (misalnya oleh para pemilik diskotik atau strip club) karena tatapan ini mampu menyuguhkan kenikmatan yang intensif bagi mereka yang memiliki uang, perkampungan miskin tempat kaum kelas bawah tinggal justru bisa menjadi wilayah yang lebih beradab dan lebih menghargai perempuan dengan menjadi tidak relevannya tatapan laki-laki di tempat ini. Justru di tempat yang minim peraturan dan pengaturan seperti ini, seperti halnya dengan batas antara penonton dan penyanyi yang cenderung cair, laki-laki dan perempuan tidak berada dalam dua kubu berlawanan di mana terjadi relasi kuasa ketika laki-laki dengan segenap kekuatan (fisik maupun tatapannya) berusaha mensubordinasi perempuan.

Menariknya, konflik yang terjadi justru bukan antara laki-laki dan perempuan, namun antarsesama laki-laki sendiri. Pada suatu pentas musik dangdut, massa yang ia tinggalkan menuntut supaya ia tetap menyanyi dan tidak menyelesaikan pertunjukan karena mereka belum puas. Ketika Patrice tidak kembali, dua orang laki-laki di antara penonton mulai berkelahi, dan Patrice diundang untuk menyanyikan satu buah lagu lagi oleh pihak panitia untuk menenangkan massa supaya situasi tidak semakin memburuk. Ketika Patrice menyanyi, perkelahian mereda dan akhirnya berhenti. Seluruh penonton kembali bergoyang, bahkan dua lelaki yang berkelahi tersebut berdamai. Ketika Patrice turun panggung untuk mendamaikan dua lelaki ini, ia tidak mengalami pelecehan apa pun baik secara verbal maupun fisik. Penonton tetap berpusat pada lagu dangdut yang ia nyanyikan. Bahkan 
ketika dua lelaki tersebut naik ke atas panggung untuk bernyanyi dan menari bersamanya, mereka sama sekali tidak memandang ke arah tubuh Patrice. Mereka sibuk berkonsentrasi menikmati lagu yang dinyanyikan Patrice dan goyangan tubuh mereka sendiri. Kembali tatapan laki-laki menjadi sesuatu yang tidak bermakna di perkampungan ini, dan laki-laki dan perempuan tidak berada dalam relasi kuasa di mana perempuan lebih inferior dan berada di bawah kekuasaan pria.

Meski demikian, dalam dua adegan pertunjukan dangdut yang lain, ditampakkan bahwa penonton memandang ke arah Patrice tanpa berkonsentrasi pada goyang dangdut mereka sendiri. Uniknya, penonton di kedua adegan ini bukanlah benar-benar penonton laki-laki dengan kepentingannya yang eksploitatif. Pada pertunjukan pertama, penontonnya terdiri dari bapak-bapak, ibu-ibu, anak-anak, atau semua orang di sekeliling rumah Mamat, yang terdiri dari keluarga-keluarga. Pada pertunjukan yang kedua, penontonnya justru kebanyakan terdiri dari para tahanan perempuan di sebuah lembaga pemasyarakatan.

Rudi Soejarwo tidak memberi kesempatan pada laki-laki untuk meletakkan perempuan dalam posisi subordinat melalui tatapan mereka. Maka, perkampungan miskin bisa menjadi sebuah arena negosiasi yang positif, karena justru perempuan mampu memegang kendali, menjadi penentu baik-buruknya keadaan, dan tidak menjadi korban dari tatapan laki-laki.

Sampai pada titik ini, ternyata Patrice belum menerima pemahaman bahwa ia bisa memiliki beberapa identitas sekaligus, dan bahwa tempat dan konteks di mana ia berada jauh lebih berperan dalam menentukan identitasnya daripada perasaan atau keyakinannya sendiri akan ketunggalan identitas. Dialog berikut menggambarkan hal tersebut:

Patrice : Gua pengin kayak dulu, Kak, terkenal, kaya, penyanyi pop rock. Nggak kayak sekarang, penyanyi dangdut, kenal sama Iyem, Yatno, dan sejuta anak kampung lain. Lu bisa nggak sih, Kak, balikin gue kayak dulu lagi?

Yulia : Balikin kayak dulu lagi? Apanya yang berubah? Selain musik kita yang berubah mendadak dangdut, nggak ada yang berubah. Lu tetep terkenal, lu tetep jadi bintang.

Yulia justru mengungkapkan sesuatu yang sangat signifikan, yaitu bahwa identitas seseorang lebih ditentukan oleh faktor eksternal, atau faktor sosial. Bagi Yulia, tidak ada yang berubah dalam diri Patrice, selain jenis irama yang ia nyanyikan. Pada dasarnya, Patrice tetaplah seorang penyanyi. Namun, konstruksi sosial membuat seolah-olah musik dangdut lebih inferior daripada jenis musik yang lain, yang akhirnya, menurut Patrice, juga telah membuat dirinya inferior dan tidak berharga. Yulia mampu melihat adanya kesia-siaan pada esensialisme identitas ini, yaitu bahwa selamanya seorang penyanyi pop rock dengan sendirinya jauh lebih baik daripada seorang penyanyi dangdut. Padahal, dalam konteks di mana kini mereka berada, pembedaan high-culture dan low-culture semacam itu tidak berlaku lagi. Pembedaan ini menjadi tidak 
relevan karena terbukti bahwa Patrice tidak pernah bisa menguasai cengkok dangdut dengan sempurna, bahkan sampai film berakhir.

Patrice adalah individu yang mengklaim dirinya (secara implisit) sebagai anggota dari komunitas high-culture, namun menjadi nyata bahwa apa yang dianggapnya low-culture ternyata tidak inferior dibandingkan dengan highculture. Bagi penduduk kampung setempat, musik yang bagus adalah musik yang bisa mereka nikmati. Inilah sebabnya nama Patrice tidak dikenal oleh penduduk kampung tersebut karena ia selalu menyanyikan lagu-lagu poprock sebelum ia datang ke kampung tersebut. Padahal, identitas Patrice sekarang lebih banyak dibentuk oleh konteks setempat: kini ia adalah Iis Maduma, nama baru yang diberikan oleh Rizal, dan ia tetap terkenal meski dengan mengusung nama dan jenis musik yang berbeda. Individu yang sama kini memiliki dua identitas yang berlainan, meski sayangnya belum bisa diterima oleh sang pemilik identitas itu sendiri.

Sampai pada tahap ini, seolah-olah perkampungan tersebut adalah suatu dunia tersendiri yang mampu membentuk identitas-identitas bagi individuindividu yang memasukinya. Namun sesungguhnya, kampung tersebut juga mendapat pengaruh signifikan dari dunia luar, yakni dunia global. Sesuai dengan pemikiran dalam geografi budaya, tempat tidak hanya menentukan bentuk dan identitas dari entitas yang ada di dalamnya, namun tempat juga dibentuk oleh entitas luar yang berhubungan dengan tempat tersebut. Kampung tersebut menjadi wilayah pergulatan antara kekuatan-kekuatan setempat (lokal) dan kekuatan-kekuatan global. Kampung tersebut akhirnya tidak bisa mendefiniskan diri berdasarkan apa yang ada pada mereka saja, karena mereka pun kini harus berhadapan dengan kekuatan-kekuatan global yang juga berusaha untuk membentuk mereka. Mereka tidak bisa melepaskan dari globalisasi sebagai kekuatan raksasa masa kini, dan kita pun diperhadapkan pada pertemuan global-lokal yang memilukan dalam film ini, yaitu dengan disiksanya ibu Mamat oleh majikannya di luar negeri.

Pertemuan dengan globalisasi dalam film ini nampak sebagai sesuatu yang negatif. Pertemuan lokal-global yang kita saksikan berwujud "feminization of migration", yang ditandai dengan membanjirnya pekerja-pekerja migran perempuan dari dunia ketiga ke dunia pertama atau negara-negara yang relatif lebih kaya. Arlie Russell Hochschild dan Barbara Ehrenreich (2004: 299, 301) menyebut fenomena ini sebagai "the female underside of globalization", di mana kini jutaan perempuan dari negara-negara miskin dan berkembang bermigrasi ke negara-negara yang lebih kaya untuk mengerjakan pekerjaan yang sudah ditinggalkan oleh perempuan-perempuan di negara yang lebih maju tersebut, atau karena penduduk negara-negara kaya tersebut tidak lagi mau mengerjakan pekerjaan-pekerjaan domestik dan pekerjaan-pekerjaan kasar. Pekerjaan ini bersifat "caring work" yang membutuhkan perhatian dan ketelitian, dan juga berhubungan dengan hasrat seksual, yaitu dengan banyaknya jumlah perempuan-perempuan dunia ketiga yang menjadi pekerja seks di negara-negara kaya. Negara-negara kaya dianggap telah kehabisan sumber daya pekerja-pekerja kasar, dan hanya bisa didapat dengan 
mengimpor tenaga-tenaga tersebut dari negara-negara miskin. Di samping itu, datangnya pekerja seks perempuan adalah untuk memuaskan hasrat laki-laki akan sosok perempuan tradisional - yang lembut, keibuan, penuh perhatian, dan patuh - yang kini telah hilang di negara-negara maju. Migrasi perempuan di era globalisasi menjadi sebuah gendered space, di mana kekuatankekuatan bersifat maskulin (negara, kekuatan ekonomi dalam ekonomi pasar yang berbasiskan kompetisi, kekuatan teknologi, serta hasrat seks laki-laki) bersifat eksploitatif terhadap perempuan.

Akhirnya kampung tersebut, yang diwakili oleh ibu Mamat, pun harus memasuki globalisasi, dan sekaligus menjadi korban dari globalisasi, yang ditandai oleh relasi kuasa karena kekuatan-kekuatan yang tidak seimbang dan eksploitatif. Kekerasan yang mendera tubuh Mpok Diah, ibu Mamat, seakanakan menjadi representasi dari masifnya hantaman kekuatan globalisasi pada diri mereka yang tidak mendapat tempat di dalamnya. Namun, meskipun menjadi pihak yang lemah, penduduk perkampungan tersebut masih menunjukkan rasa kemanusiaan serta kemampuan untuk bertahan di tengah himpitan masalah-masalah sosial dan ekonomi yang mendera mereka. Mereka mau menyumbang uang demi membantu ibu Mamat untuk menyunatkan Mamat dan mungkin juga membeli obat-obatan untuk dirinya sendiri.

Namun, pada akhirnya titik balik itu tercapai juga. Setelah tampil dalam pertunjukan dangdut amal untuk biaya sunat Mamat, Patrice sadar bahwa ia bisa berbuat banyak dengan kemampuannya menyanyi dangdut. Ia telah mampu membuat Mpok Diah tersenyum ketika ia menyanyi, sesuatu yang menurut Patrice sangat sulit untuk dilakukan oleh Mpok Diah karena lukaluka di wajahnya. Patrice yang semula meremehkan Yati Asgar, penyanyi dangdut dari Garut yang melatihnya bernyanyi dangdut, kini malah berterima kasih padanya:

Patrice : Yati Asgar, lu bener banget, men. Gue ngerti maksud lu sekarang. Gue bakal lanjutin perjuangan lu. Garut, is the best.

Pada titik ini, Patrice telah merasa nyaman dengan identitasnya yang baru sebagai penyanyi dangdut. Ia telah membuktikan sendiri bahwa menyanyi dangdut adalah menyanyi dengan misi tertentu karena dengan musik ini ia tidak melayani dirinya sendiri namun berbuat demi kepentingan orang banyak, sesuatu yang mungkin lebih sering diucapkan oleh penyanyi poprock tetapi jarang dilakukan. Justru pendapat ini telah ia buktikan sendiri kebenarannya sebagai seorang penyanyi dangdut. Dengan dangdut ia bisa berbuat lebih banyak bagi orang lain daripada bagi dirinya sendiri. Ketika pada akhirnya terbukti tidak bersalah, Patrice akan kembali pada statusnya semula sebagai penyanyi pop, namun kini ia telah nyaman dengan identitasnya sebagai penyanyi dangdut.

Kini ia bisa berpindah, melompat, dan bergerak di antara dua konteks dan tempat yang berbeda: di studio, di mal, di restoran mewah, di mobilnya sendiri, di rumahnya yang nyaman, maupun di gang kotor dan sempit, di rumah kontrakan murah, dan di sepetak tanah lapang di antara rumah-rumah 
sederhana di tengah kampung miskin. Dua identitas yang berbeda, dan fluiditas di antaranya, telah banyak dibentuk dan ditentukan dari tempat di mana ia berada. Ini membuktikan eratnya hubungan antara tempat dan budaya serta identitas, dan menunjukkan bagaimana tempat, budaya, dan identitas saling mempengaruhi untuk menciptakan fleksibilitas dalam identitas.

\section{KeSIMPULAN}

Dari uraian di atas dapat disimpulkan bahwa lingkungan perkotaan tidak pernah bisa dimaknai secara tunggal. Satu definisi dan representasi mengenai kota adalah sesuatu yang tidak lagi relevan. Kota adalah sebuah ranah negosiasi di mana terjadi proses pembentukan identitas, representasi, dan pemaknaan baru yang berlangsung terus menerus. Budaya kota dipengaruhi oleh faktor ruang, dan oleh ruang inilah negosiasi, konflik, persinggungan dan pergeseran identitas, budaya, dan representasi terus berjalan.

Mendadak dangdut menunjukkan pada kita bahwa yang diperlukan oleh penghuni perkotaan adalah sebuah fleksibilitas untuk sekaligus merangkul beberapa identitas. Film ini menunjukkan bahwa bagi individu penghuni perkotaan, mengasosiasikan diri pada kelas sosial dan budaya tertentu dalam lingkungan perkotaan menjadi sesuatu yang tidak berguna. Yang diperlukan bagi warga kota adalah sebuah kecairan identitas, di mana kita bisa melompat dari satu identitas ke identitas yang lain, bukan untuk menunjukkan kelemahan kepribadian kita, namun justru untuk menekankan pemahaman bahwa kontinuitas kehidupan perkotaan lebih banyak bergantung pada multiplicity of identities daripada identity essentialism. Film ini juga mengajarkan bahwa representasi tertentu mengenai suatu fenomena budaya tidak pernah kekal, dan justru perbedaan pemaknaan akan fenomena inilah yang harus senantiasa kita tampilkan.

Film Mendadak dangdut juga memperlihatkan bahwa terdapat representasi tertentu mengenai suatu daerah perkotaan yang bisa berbeda atau bertolak belakang dengan kenyataan dan kehidupan sesungguhnya dari para penghuni wilayah tersebut. Representasi ini selalu mengambil sudut pandang atau sudut berdiri tertentu, dan sudut pandang ini bisa dipenuhi dengan kepentingan-kepentingan, yang kerap berhubungan dengan kekuasaan. Namun, representasi bisa berlawanan dengan kenyataan, dan representasi bisa menyesatkan kita pada pemahaman bahwa seakan-akan fenomenafenomena tertentu (misalnya pelecehan seksual yang dialami oleh penyanyi dangdut perempuan di perkampungan miskin, atau kenikmatan memandang yang dimiliki kaum pria di perkampungan tersebut ketika menyaksikan pertunjukan dangdut) secara alami memang harus muncul berkaitan dengan tempat atau lokasi tertentu. Sesungguhnya, fenomena-fenomena ini tidak selalu berkaitan dengan representasi, namun justru interaksi sosial-budaya masyarakat yang berbeda-beda di setiap tempat lebih berperan dalam memunculkan fenomena-fenomena budaya yang bervariasi. Kembali film ini mengajak kita untuk memahami bahwa terdapat kekayaan tersendiri dalam perbedaan pemaknaan akan tempat, dan bahwa dalam diversitas ini kita akan 
mampu membangun pemahaman akan perkotaan dan budaya perkotaan yang lebih positif dan kondusif.

\section{DAFTAR PUSTAKA}

Baldwin, Elaine, et al. 2004. Introducing cultural studies. New Jersey: Prentice Hall.

Barker, Chris. 2000. Cultural studies; Theory and practice. London: Sage Publications.

Budiman, Manneke. 2003. “Iklan sebagai fetish kultural; Sebuah kajian psikoanalitis atas kebudayaan populer", Anggadewi Moesono (red.), Psikoanalisis dalam sastra, hlm. 125-155. Depok: Pusat Penelitian Kemasyarakatan dan Budaya, Lembaga Penelitian Universitas Indonesia.

Giles, Judy and Tim Middleton. 1999. Studying culture; A practical introduction. Oxford: Blackwell Publishers.

Hochschild, Arlie Russell and Barbara Ehrenreich. 2004. "Global woman”, di dalam: Ann Waters (red.), Global exchange; Reading and writing in a world context, hlm. 297-310. New Jersey: Prentice Hall.

Jackson, Peter. 1989. Maps of meaning; An introduction to cultural geography. London: Routledge.

Paramadhita, Intan. 2007. "Pasir berbisik and new women's aesthetics"; Jump Cut; A Review of Contemporary Media 49, (http:// ejumpcut.org/ currentissue/PasirBerbisik/index.html), diakses 20 Juni 2007.

Sasono, Eric. 2007. “Ini bukan badut, ini dangdut", (http://layarperak.com/ print.php?newsid=1155669538), diakses 19 Juni 2007.

Storey, John. 2007. Cultural studies dan kajian budaya pop; Pengantar komprehensif teori dan metode. Diterjemahkan oleh Laily Rahmawati. Yogyakarta: Jalasutra. (Judul asli Cultural studies and the study of popular culture; Theory and methods, Edinburgh: Edinburgh University Press, 2003).

Weeks, Jeffrey. 1990. "The value of difference", di dalam: J. Rutherford (red.), Identity; Community, culture, difference, hlm. 88-89. London: Lawrence and Wishart.

Westwood, S. dan J. Williams. 1997. The language of youth subculture. Hemel Hempstead: Harvester Wheatsheaf.

Woodward, Kathryn. 1997. Identity and difference. London: Sage Publications. 